Journal of Animal and Veterinary Advances 9 (1): 199-204, 2010

ISSN: $1680-5593$

(C) Medwell Journals, 2010

\title{
Polymorphism in Intron-1 of ApoVLDL-II Gene and its Association with Meat Quality and Fatness Traits in Duck
}

\author{
${ }^{1,2}$ Zhang Yi-Yu, ${ }^{1}$ Chen Guo-Hong, ${ }^{1} \mathrm{Xu}$ Qi, ${ }^{1}$ Zhang Hai-Bo, \\ ${ }^{3}$ Duan Xiu-Jun, ${ }^{3}$ Sun Guo-Bo and ${ }^{1}$ Zhao Wen-Ming \\ ${ }^{1}$ College of Animal Science and Technology, Yangzhou University, Yangzhou Jiangsu 225009, China \\ ${ }^{2}$ College of Animal Science, Guizhou University, Guiyang 550025, China \\ ${ }^{3}$ College of Jiangsu Animal Husbandry and Veterinary, Taizhou Jiangsu 225300, China
}

\begin{abstract}
Very Low Density apolipoprotein-II (apoVLDL-II) is a major constituent of Very Low Density Lipoprotein (VLDL) and is involved in lipid transportation in bird species. The current study was designed to investigate the associations of an apoVLDL-II gene intron-1 polymorphism on duck meat quality and fatness traits. The results showed that there were two alleles (A and $\mathrm{B})$ and three genotypes $(\mathrm{AA}, \mathrm{AB}$ and $\mathrm{BB})$ in the experimental populations. AA genotype and A allele frequency were highest. Eight SNPs (T667C, C669G, T673C, G674A, G683A, G688A, C708G and T715G) and inserted/deleted GT after position 764 bp were found by sequencing. The apoVLDL-II gene intron-1 polymorphism was associated with multiple traits of meat quality and fatness in the 170 individuals, including $\mathrm{pH}$-value, tenderness, water holding capacity, IMF, serum total cholesterol, serum triglyceride and abdominal fat. This research suggests that apoVLDL-II intron-1 has broad effects on meat quality and fatness traits in duck.
\end{abstract}

Key words: Duck, apoVLDL-II gene, polymorphism, meat quality, fatness traits, association analysis

\section{INTRODUCTION}

Although, intensive selection in duck has made great improvement in growth rate and feed efficiency, modern strains of ducks exhibit excessive body fat deposition. That is one of the main problems encountered by the duck industry today, because it has significant negative effects on feed efficiency and causes great economic loss to processing plants. The economic concern and recognition of consumer aversion to excess fatty tissue deposition have led commercial breeders to incorporate significant selection for reduced body fatness in their breeding programs. Therefore, considerable research effort has been applied to study factors associated with fat deposition and methods to reduce it (Wawro et al., 2004). The candidate gene approach is a powerful method for finding the QTL responsible for genetic variation in traits of interest in agricultural animal species (Lamont et al., 1996; Bai et al., 2006). Similar to other economically important traits, most duck meat quality and fitness traits are controlled by multiple genes. Understanding the genetic control of meat quality and fitness traits in duck will provide an opportunity for genetic enhancement of production performance (Deeb and Lamont, 2002). The combination of traditional genotic and breeding methods and modern molecular methods may be preferred for genotic improvement of duck in the future.

Very Low Density apolipoprotein-II (ApoVLDL-II) is a small phospholipid-binding protein (Binder et al., 1990). It is a major polypeptide component of Very Low Density Lipoprotein (VLDL) and is involved in lipid transportation in avian. Its function is the transport of neutral lipids in the form of very low density lipoprotein in the plasma. The apoVLDLII gene is normally dormant in males but can be activated by the administration of estrogen and specifically expressed in liver (Pinchasov et al., 1994; Tejada et al., 1999). The expression of ApoVLDL-II protects ApoVLDL-II containing very low density lipoprotein so that it can be transported to the ovary and not hydrolyzed by lipoprotein lipase in other peripheral tissues in laying brids. Laying may affect particular aspects of lipid metabolism, especially biochemica 1 pathways in which ApoVLDL-II and $\mathrm{HMG}-\mathrm{CoA}$ reductase are involved (Yen et al., 2005). Thus, ApoVLDL-II is a candidate gene for traits related to fat deposition and then it affect on meat quality possibly. However, up to now, the research about SNPs of the ApoVLDL-II gene in duck was not reported. The objectives of the present study were to identify SNPs in the duck ApoVLDL-II gene intron-1 and to evaluate associations between the polymorphisms and meat quality and fatness traits in three duck populations.

Corresponding Author: G.H. Chen, College of Animal Science and Technology, Yangzhou University, Yangzhou, 225009, China 


\section{MATERIALS AND METHODS}

Sanples collection and preparation: Blood samples were collected from 170 individuals belongs to three duck populations: Cherry Valley duck, (CV) (55), Jinding Duck, (JD) (55) and Hybrid duck (CV x JD) (HB) (60). The blood samples were collected from College of Jiangsu Animal Husbandry and Veterinary. Ducks were reared in the same management system. The 170 ducks were slaughtered at the end of 70 days. The meat quality and fatness traits such as $\mathrm{pH}$, tenderness (shear value) $\left(\mathrm{kg} \mathrm{cm} \mathrm{cm}^{-2}\right)$, meat colour $\left(\mathrm{OD}_{\mathrm{s}+0}\right)$, water holding capacity $(\%)$, Intramuscular Fat (IMF) (\%), serum total cholesterol ( $\left.\mathrm{mmol} \mathrm{L}^{-1}\right)$, serum triglyceride ( $\mathrm{mmol} \mathrm{L} \mathrm{L}^{-1}$ ) and abdominal fat $(\%)$ in these ducks were collected for statistical analysis. Genome DNA was obtained by phenol and chloroform (1:1) extraction and stored at $-20^{\circ} \mathrm{C}$.

Primer design and PCR amplific ation: $B$ ased upon duck ApoVLDL-II gene sequences (Accession no. GQ180104), four pair primers ( Table 1) were designed using the Oligo 6.0 program to amplify the duck ApoVLDL-II gene intron-1 and detect the single nucleotide polymom hisms. Following optimization, $\mathrm{PCR}$ reactions were carried out in a total volume of $25 \mu \mathrm{L}$ with $100 \mathrm{ng}$ of genomic DNA, 5 pmol of each of forward and reverse primer, $2.5 \mu \mathrm{L}$ of $10 \times$ buffer, $1.5 \mathrm{mM}$ of $\mathrm{MgCl} 2,0.16 \mathrm{mM}$ of dNTP and $1 \mathrm{U}$ of Taq DNA polymerase (Fermentas). PCR program initial denaturation for $10 \mathrm{~min}$ at $95^{\circ} \mathrm{C}, 30 \mathrm{cycles}$ each $45 \mathrm{sec}$ at $94^{\circ} \mathrm{C}, 45 \mathrm{sec}$ at $58^{\circ} \mathrm{C}$ and $45 \mathrm{sec}$ at $72^{\circ} \mathrm{C}$ and $10 \mathrm{~min}$ final extencion at $72^{\circ} \mathrm{C}$.

Single Stranded Sonformation Polymorphism (SSCP) and sequencing: Adiquots of $5 \mu \mathrm{L}$ PCR products were mixed with $10 \mu \mathrm{L}$ denaturing solution ( $98 \%$ formamide, $25 \mathrm{mM}$ EDTA, $0.025 \%$ xylene-cyanole and $0.025 \%$ bromophenol blue), heated for $10 \mathrm{~min}$ at $98^{\circ} \mathrm{C}$ and cooled on ice. Denatured PCR products were subjected to $10 \%$ actylamide: bisactylamide (39:1) gels in $1 \times$ TBE buffer and constant voltage $(130 \mathrm{~V})$ for $12-14 \mathrm{~h}$. The gel was stained with $0.1 \%$ silver nitrate. PCR fragments from different

Table 1: Frimers fa ApoVLDL-I gave itron-land PCR mabsis purameters intablichod for duck

\begin{tabular}{|c|c|c|c|}
\hline Primars & Primor m quxpe $\left(5^{\prime}-3\right)$ & $\begin{array}{l}\text { Fragumt } \\
\text { lomgen }(b p)\end{array}$ & 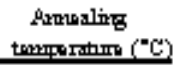 \\
\hline Al & $\begin{array}{l}\text { F: GGACCTTTGACCCCTCACTA } \\
\text { R: GCCCTCCTATGAGTGTCCTATG }\end{array}$ & 260 & 58 \\
\hline $\mathrm{A} 2$ & $\begin{array}{l}\text { F: GCCACTACCTGGAACAGGATT } \\
\text { R CAGCCTCATCCAACATCCTT } \\
\text { F. CCA TTETCT }\end{array}$ & 285 & 55 \\
\hline A4 & $\begin{array}{l}\text { R: TTGCAAATGGCTCTAACGAA } \\
\text { F: TGTAACTGCCACAGATTCCTTG }\end{array}$ & 280 & 58 \\
\hline & R:ATGGTTTGCGGTACCAGTTC & 287 & 56 \\
\hline
\end{tabular}

SSCP patterns in different populations were sun-cloned to T-vector (Takara, China). All fragments were sequenced in both directions.

Statistical analysis: $\chi^{2}$-tests were used to determine if the individual variant was in Hardy-Weinberg equilibrium. The genotype and allele frequency distributions were compared by $\chi^{2}$-test. The association between apoVLDLII gene intron-1 and meat quality and fatness traits was evaluated according to follow model:

Where:

$$
\mathrm{Y}=\mu+\mathrm{G}+\mathrm{B}+\mathrm{G} \times \mathrm{B}+\mathrm{e}
$$

$\mathrm{Y} \quad=$ Dependent variable (analyzed traits)

$\mu \quad=$ Overall mean

$\mathrm{G}=$ Genotype of apoVLDL-II intron-1 (AA, AB and BB)

B $=$ Duck population

$\mathrm{G} \times \mathrm{B}=$ Interactions between genotype and duck population (all fixed effects)

e $\quad=$ Random error

Difference between genotypes was determined by least square analysis.

\section{RESULTS AND DISCUSSION}

SSCP in intron-l of the apo VLDL-II gene: Amplicons of the expected size were obtained from duck DNA using different primers. These were identified by PCR-SSCP mothed. The results of primer $A 1, A 3$ and $A 4$ showed no polymorphism. The amplicons of primer A2 were approximately $285 \mathrm{bp}$ in size and exhibited polymorphism in different individuals and populations. Three band patterns could be identified in intrion-1 of apoVLDL-II gene (Fig 1), which were the products of two alleles (A and $B$ ).

DNA sequencing: The sequencing results were compared with the intron-1 sequence of duck (Accession no. GQ180104) and showed: BB genotype sequences and GQ180104 was identical was defined as mutant-type, AA genotype as wild-type. Alignment sequences results

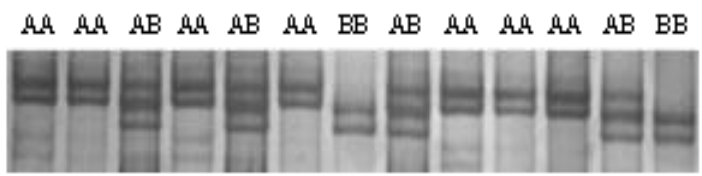

Fig. 1: PCR-SSCP band pattern on a $10 \%$ non-denaturing polyactylamide gel 

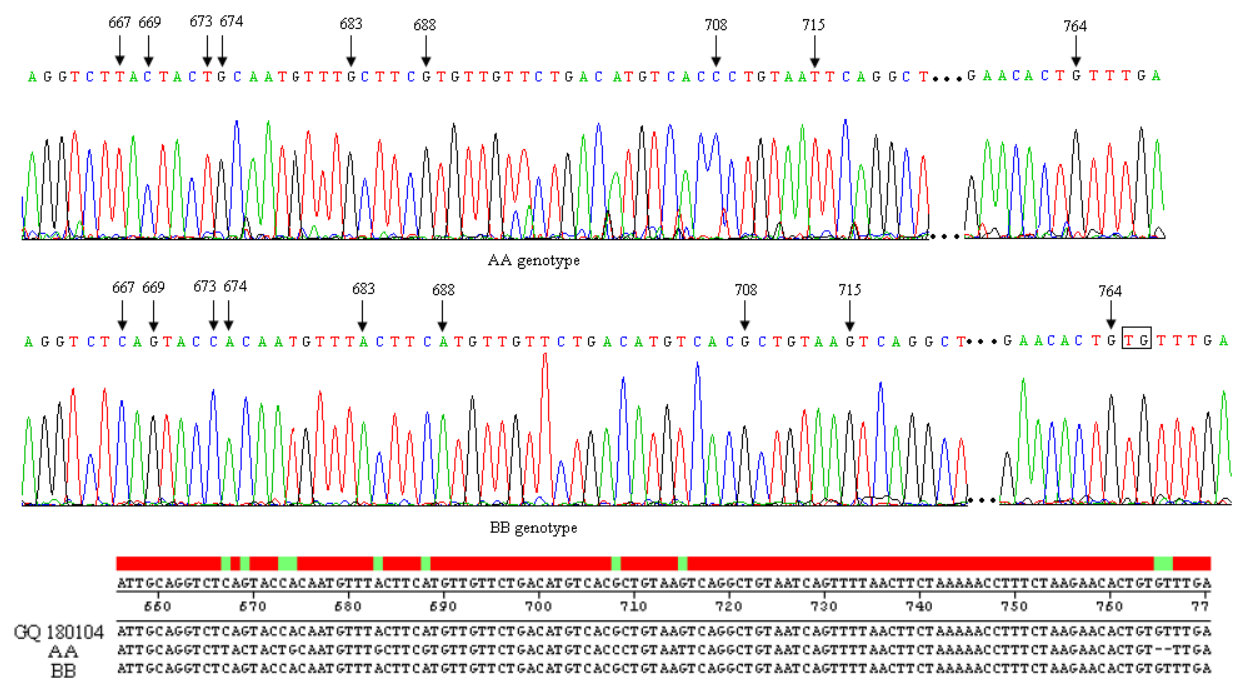

Fig. 2: The sequencing result of $\mathrm{AA}$ and $\mathrm{BB}$ genotypes (The arrows indicated mutation positions, the inserted/deleted fragments were bold with the frame)

Table 2: Allele and genotype frequencies of the SNP in intron-1 of apoVLDL-II gene in three duck populations Genotype frequencies Allele frequencies

\begin{tabular}{|c|c|c|c|c|c|c|c|c|c|}
\hline \multirow[b]{2}{*}{ Population } & & \\
\hline & $\mathrm{AA}$ & $\mathrm{AB}$ & $\mathrm{BB}$ & $\mathrm{A}$ & B & $\mathrm{h}$ & $\mathrm{Ne}$ & PIC & $\chi^{2}(\mathrm{HWE})$ \\
\hline $\mathrm{CV}$ & 0.8182 & 0.0545 & 0.1273 & 0.8455 & 0.1545 & 0.2612 & 1.3535 & 0.2270 & $12.93^{* * *}$ \\
\hline JD & 0.4909 & 0.0727 & 0.4364 & 0.5273 & 0.4727 & 0.4986 & 1.9944 & 0.3744 & $25.43^{* * *}$ \\
\hline $\mathrm{HD}$ & 0.5500 & 0.4500 & 0.0000 & 0.7750 & 0.2250 & 0.3488 & 1.5356 & 0.2880 & 3.88 \\
\hline
\end{tabular}

$\mathrm{CV}=$ Cherry Valley duck; $\mathrm{JD}=$ Jinding Duck; $\mathrm{HB}=$ Hybrid duck of $\mathrm{CV} \times \mathrm{JD} ; \mathrm{h}=$ Heterozygosity; $\mathrm{Ne}=$ Effective number of alleles; PIC $=$ Polymorphism Information Content; $\chi^{2}(\mathrm{HWE})=$ Hardy - Weinberg Equilibrium $\chi^{2}$ value, ${ }^{* *}(\mathrm{p}<0.01)$

Table 3: Least square analysis between intron-1 of apoVLDL-II and meat quality and fatness traits in duck

\begin{tabular}{|c|c|c|c|}
\hline$\underline{T r a i t s}$ & $\begin{array}{c}\text { Genotype AA } \\
(\mathrm{n}=105)\end{array}$ & $\begin{array}{c}\text { Genotype } A B \\
(n=34)\end{array}$ & $\begin{array}{c}\text { Genotype BB } \\
(\mathrm{n}=31)\end{array}$ \\
\hline pH-value & $6.00 \pm 0.03^{\mathrm{a}}$ & $5.96 \pm 0.04^{a}$ & $6.21 \pm 0.04^{b}$ \\
\hline Meat colour $\left(\mathrm{OD}_{540}\right)$ & $1.04 \pm 0.04$ & $1.00 \pm 0.06$ & $1.15 \pm 0.06$ \\
\hline Shear value $\left(\mathrm{kg} \mathrm{cm}^{-2}\right)$ & $1.99 \pm 0.07^{\mathrm{a}}$ & $2.26 \pm 0.11^{\mathrm{b}}$ & $2.09 \pm 0.11^{\mathrm{ab}}$ \\
\hline Water holding capacity (\%) & $18.82 \pm 0.62^{\mathrm{a}}$ & $15.20 \pm 0.96^{b}$ & $14.42 \pm 0.98^{b}$ \\
\hline Intramuscular Fat (IMF) (\%) & $8.80 \pm 0.30^{\mathrm{a}}$ & $7.23 \pm 0.45^{b}$ & $7.48 \pm 0.50^{b}$ \\
\hline Serum total cholesterol $\left(\mathrm{mmol} \mathrm{L}^{-1}\right)$ & $5.75 \pm 0.27^{\mathrm{a}}$ & $4.87 \pm 0.43^{b}$ & $6.75 \pm 0.42^{c}$ \\
\hline Serum triglyceride $\left(\mathrm{mmol} \mathrm{L}^{-1}\right)$ & $1.06 \pm 0.27^{\mathrm{a}}$ & $1.09 \pm 0.43^{\mathrm{a}}$ & $1.39 \pm 0.42^{b}$ \\
\hline Abdominal fat (\%) & $1.27 \pm 0.30^{\mathrm{a}}$ & $0.77 \pm 0.48^{b}$ & $0.92 \pm 0.52^{\mathrm{ab}}$ \\
\hline
\end{tabular}

abc: Significantly different (LSD test,p $<0.05$ ) in genotypes AA, AB and BB; n: Number of the genotype in the population

showed that eight SNPs, T667C, C669G, T673C, G674A, G683A, G688A, C708G and $\mathrm{T} 715 \mathrm{G}$ and one insertion/deletion (the inserted/deleted GT after position $764 \mathrm{bp}$ ) were found in intron-1 in 170 duck from three populations (CV, JD and $\mathrm{HD}$ ) (Fig. 2). Therefore, there are multiple mutations in the region from $667-764 \mathrm{bp}$.

Allele and genotype distribution: In three duck populations, genotype frequency of AA was highest. The A allele frequencies for the intron-1 of apoVLDL-II gene in the analyzed populations were $0.8455,0.5273$ and 0.7750 for $\mathrm{CV}, \mathrm{JD}$ and $\mathrm{HD}$ populations, respectively. The genotype distributions of $\mathrm{CV}$ and JD in disagreement with Hardy-Weinberg equilibrium $(\mathrm{p}<0.05)$ except $\mathrm{HD}$ population (Table 2). The locus belonged to medium polymorphism in $\mathrm{D}$ and $\mathrm{HD}$ populations $(0.25<\mathrm{PIC}<0.5)$. For CV population, it was low polymorphism $(\mathrm{PIC}<0.25)$.

Allelic effect of the apoVLDL-II gene intron-1 on some meat quality and fatness traits: The allelic effects of the apoVLDL-II Gene intron-1 on some meat quality and fatness traits in 170 samples of three duck populations were shown in Table 3. For meat quality and fatness traits with significant differences between genotypes, the allelic effect of $\mathrm{pH}$-value, shear value, Water holding capacity, IMF, serum total cholesterol, serum triglyceride and abdominal fat acted in a dominant mode. The bird with homozygote (AA) had significant higher than 
Table 4: Effects (P-value) of polymorphism of apoVLDL-II gene intron-1 on duck meat quality and fatness traits

\begin{tabular}{|c|c|c|c|}
\hline Trait & Genotype & Population & Genotype x Population \\
\hline $\mathrm{pH}$-value & $<0.001$ & $<0.001$ & $<0.001$ \\
\hline Meat colour $\left(\mathrm{OD}_{540}\right)$ & 0.303 & 0.113 & 0.041 \\
\hline Shear value $\left(\mathrm{kg} \mathrm{cm}^{-2}\right)$ & 0.022 & $<0.001$ & $<0.001$ \\
\hline Water holding capacity (\%) & $<0.001$ & $<0.001$ & $<0.001$ \\
\hline Intramuscular fat $(\%)$ & 0.004 & $<0.001$ & $<0.001$ \\
\hline Serum total cholesterol $\left(\mathrm{mmol} \mathrm{L}^{-1}\right)$ & $<0.001$ & $<0.001$ & $<0.001$ \\
\hline Serum triglyceride $\left(\mathrm{mmol} \mathrm{L}^{-1}\right)$ & 0.002 & $<0.001$ & $<0.001$ \\
\hline Abdominal fat (\%) & 0.015 & $<0.001$ & $<0.001$ \\
\hline
\end{tabular}

heterozygotes (AB) and homozygotes (BB) for waterholding capacity and IMF. However, for shear value, the birds with heterozygote $(\mathrm{AB})$ had significant higher than homozygotes (AA). The birds with homozygotes (BB) had significant higher than homozygotes (AA) and heterozygote $(\mathrm{AB})$ for $\mathrm{pH}$-value, serum triglyceride and serum total cholesterol. For abdominal fat and serum total cholesterol, the homozygotes (AA) had significant higher than heterozygotes (AB). Furthermore, no significant association of different genotypes with other traits were detected $(p>0.05)$. The results indicated that the locus linked strongly with the QTL controlling meat quality and fatness traits. Therefore, it was presumed that it may have a QTL controlling fatness and meat quality in the region.

Interaction between the apoVLDL-II gene intron-1 and genetic background of three duck populations: The interactions between the genotypes of apoVLDL-II gene intron-1 and genetic background of three duck populations were showed in Table 4 . Only the meat colour had not genotype and population effect $(\mathrm{p}>0.05)$ and then other traits were significant genotypes and populations and genotype $x$ population effects $(\mathrm{p}<0.05)$.

The apoVLDL- $\Pi$ is a member of the avian yolk protein gene family (Wiskocil et al., 1981). The apoVLDL-II gene promoter contains many regulatory elements that have been previously related with gene expression. The apoVLDL-II gene also contains sequences within its first intron that increase transcription (Schippers et al., 1994). By using in vitro DNaseI footprinting, 6 protein-binding sites were revealed throughout the first intron and those protein-binding sites effect expression of apoVLDL-II gene and other correlative gene (Shuler et al., 1998). At the same time, Li et al. (2005) found a G634A mutation (GenBank accession no: V00448) in the first intron of the apoVLDL- $\Pi$ gene and the G/A mutation has broad effects on growth and development in the chicken. Cheng et al. (2008) reported four mutation (G950 A, A 2522 C, A 2705 C and C2793T) in intron-1 and the 4 SNPs have remarkable genetic effect for the meat quality (tenderness and $\mathrm{pH}$ ) in chicken. In this study, we found
8 SNPs, T667C, C669G, T673C, G674A, G683A, G688A, $\mathrm{C} 708 \mathrm{G}$ and $\mathrm{T} 715 \mathrm{G}$ and one insertion/deletion (the inserted/deleted GT after position $764 \mathrm{bp}$ ) in intron-1 of apoVLDL-II gene in three duck populations (170 individuals), but only which resulted in 3 genotypes: $\mathrm{AA}, \mathrm{AB}$ and $\mathrm{BB}$. In three duck populations, AA genotype and $\mathrm{A}$ allele frequency were highest. The genotype distributions of CV and JD in disagreement with HardyWeinberg equilibrium $(\mathrm{p}<0.05)$. The locus belonged to medium polymorphism in $\mathrm{D}$ and $\mathrm{HD}$ populations $(0.25<\mathrm{PIC}<0.5)$. For $\mathrm{CV}$ population, it was low polymorphism $(\mathrm{PIC}<0.25)$. One explanation could be they were suffered intensive selection during the long term commercial breeding. In selected populations, deviations of genotype frequencies from the Hardy-Weinberg equilibrium should be expected for loci with impact on traits under selection.

Poultry meat quality and fatness traits are very important to keep up with consumer demand. Therefore, different methods have been used to reduce fatness and improve meat quality in poultry (Mullen et al., 2006). The candidate gene approach is a very powerful method to investigate associations of gene polymorphisms with economically important traits in farm animals. Many studies showed that apoVLDL-II gene play a important role in lipid transportation in poultry (Zsigmond et al., 1995; Berkowitz and Evans, 1992; Schippers et al., 1994). In this study, the apoVLDL-II gene was selected as a candidate gene to investigated associations of gene polymorphisms with some meat quality and fatness traits in three duck populations. The results indicated that breed and genotype has significant effect in these metrical indexes except meat colour by using fixed model. For $\mathrm{pH}$-value, water holding capacity, Intramuscular Fat (IMF), serum total cholesterol and serum triglyceride, there had significant difference between AA and BB genotype. The polymorphism locus linked strongly with the QTL controlling meat quality and fatness traits. This result was consistent with the study in chicken (Cheng et al., 2008). So, we conjecture the apoVLDL-II gene may be a major candidate gene or linked to major candidate gene that impact duck lipid metabolism 
and the SNPs could be used in Molecular Assistant Selection (MAS) as a genetic marker for duck fatness traits. However, an explanation for the results was also probably due to the low animal numbers. We will further test and verify to enlarge the number of samples in the future.

\section{CONCLUSION}

In this study, eight SNPs, T667C, C669G, T673C, G674A, G683A, G688A, C708G and T715G and one insertion/deletion (the inserted/deleted GT after position $764 \mathrm{bp}$ ) in apoVLDL-II gene intron 1 was found in three duck populatrions ( $\mathrm{CV}, \mathrm{D}$ and $\mathrm{HD})$, which resulted in three genotypes (AA, $\mathrm{AB}$ and $\mathrm{BB}$ ).

There have been significant breed and genotype effect on $\mathrm{pH}$-value, shear value, water holding capacity, IMF, serum total cholesterol, serum triglyceride and abdominal fat except meat colour by using fixed model. This results suggests that apoVLDL-II intron-1 has broad effects on meat quality and fat metabolism in duck.

\section{ACKNOWLEDGEMENTS}

This study was supported by Chinese National Key Programs (2006BDA01A09 and 2006BDA14B06) and Modern Agro-industry Technology Research System (nycytx-45-04).

\section{REFERENCES}

Bai, J.Y., Q. Zhang and X.P. Jia, 2006. Comparison of different foreground and background selection methods in marker-assisted introgression. Acta Genetica Sinica, 33: 1073-1080. DOI: 10. 1016/S03794172(06)60144-3. PMID: 17185166. http://www. sciencedirect.com/science?_ob=ArticleURL\&_udi= B82XC-4MM2B05-3\&_user $=1021790 \&$ rdoc $=1 \&$ _ $\mathrm{fmt}=\&$ _orig $=$ search \&_sort $=\mathrm{d} \&$ _docanchor $=\& \mathrm{view}=$ c\&_act $=$ C000050480\&_version $=1 \&$ \&urlVersion $=0$ $\&$ userid $=1021790 \& \mathrm{md} 5=\mathrm{ddc} 2 \mathrm{ff} 3516 \mathrm{a} 498458 \mathrm{fc} 7 \mathrm{~b} 80$ $13 \mathrm{e} 1 \mathrm{ab} 62 \mathrm{~d}$.

Binder, R., C.C. MacDonald, J.B Burch, C.B Lazier and D.L. Williams, 1990. Expression of endogenous and transfected apolipoprotein II and vitellogenin II genes in an estrogen responsive chicken liver cell line. Mol. Endocrinol., 4: 201-208. DOI: 10. 1210/mend4-2-201. PMID: 2330000. http://mend.endojournals. org/content/vol4/issue 2 .
Berkowitz, E.A. and M.I. Evans, 1992. Functional analysis of regulatory regions upstream and in the first intron of the estrogen-responsive chicken very low density apolipoproteinII Gene. J. Biol. Chem., 267: 7134-7138. PMID: 1372608. http://www.jbc.org/content/267/10/ 7134.full.pdf.

Cheng, J.H., W.M. Zhao, Q. Chen, J.T. Shu, X.S. Wu, H.H. Musa and G.H. Chen, 2008. Analysis on the correlation between polymorphism of introns of chicken ApoVLDL-II gene and the meat quality. J. Yangzhou Univ. (Agric. Life Sci. Edn.), 29: 37-40. DOI:CNKI:SUN:JSNX.0.2008-01-012.http://dlib.edu. cnki.net/kns 50/detail.aspx?QueryID=3\&CurRec=3.

Deeb, N. and S.J. Lamont, 2002. Genetic architecture of growth and body composition in unique chicken population. J. Hered, (93): 107-118. PMID: 12140270. http://jhered.oxfordjournals.org/cgi/reprint/93/2/107. pdf.

Lamont, S.J., N. Lakshmanan, Y. Plotsky, M.G. Kaiser, M. Kuhn, J.A. Arthur, N.J Beck, and N.P. Sullivan, 1996. Genetic markers linked to quantitative traits in poultry. Anim. Genet, 27: 1-8. DOI: 10.1111/j. 1365-2052.1996.tb01170.x. PMID: 8624031 . http://www3.interscience. wiley.com/user/accessde nied $? \mathrm{ID}=120103753 \& \mathrm{Act}=2138 \&$ Code $=4717 \&$ Page =/cgi-bin/fulltext/120103753/PDFSTART

Li, H., N. Deeb, H. Zhou, C.M. Ashwell and S.J. Lamont, 2005. Chicken quantitative trait loci for growth and body composition associated with the very low density apolipoprotein-II gene. Poult. Sci., 84: 697-703. PMID: 15913180. http://www.ncsu.edu/ ashwell-lab/publications/chris/may2005.pdf.

Mullen, A.M., P.C. Stapleton, D. Corcoran, R.M. Hamill and A. White, 2006. Understanding meat quality through the application of genomic and proteomic approaches. Meat Sci., 74: 3-16. DOI: 10.1016/j. meatsci.2006.04.015. http://www.sciencedirect.com/ science?_ob=ArticleURL\&_udi=B6T9G-4JWDY4N$2 \&$ _user $=1021790 \&$ rdoc $=1 \&$ fmt $=\&$ \&orig $=$ search $\&$ sort $=\mathrm{d} \&$ _docanchor $=\&$ view $=\mathrm{c} \&$ _searchStrId $=1$ 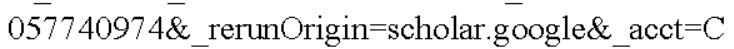 $000050480 \&$ version $=1 \&$ urlVersion $=0 \&$ userid $=1$ $021790 \& \mathrm{md} 5=\mathrm{b} 00 \mathrm{e} 3 \mathrm{fa} 740 \mathrm{c} 5 \mathrm{fdb} 22 \mathrm{alclaad} 94839 \mathrm{f} 7 \mathrm{c}$.

Pinchasov, Y., S. Elmaliah and S. Bezdin, 1994. Plasma Apolipoprotein VLDL-II and Egg Production in Laying Hens: Establishment of an Elisa Method. Reprod. Nutr. Dev., 34: 361-369. DOI: 10.1051/rnd: 19940408. PMID: 7986353. http://rnd.edpsciences. org/index.php?option $=$ article\&access $=$ standard\& Itemid=129\&url=/articles/rnd/pdf/1994/04/RND 0926-5287_1994_34_4_ART0008.pdf. 
Schippers, I.J., M. Kloppenburg, L. Snippe and G. Ab, 1994. 9-cis-retinoic acid represses estrogen-induced expression of the very low density apolipoprotein II gene. Mol. Cell. Endocrinol., 105: 175-182. DOI: 10.1016/S0169-328X(01)00020-1.PMD: 7859923. http://www.sciencedirect.com/science?_ob=Article URL\&_udi=B6T07-42H1RWF-F\&_user $=1021790 \&$ rdoc $=1 \&$ fmt $=$ \&_orig $=$ search\&_sort $=$ d\&_docanch or $=\& v i e w=c \& \_s e a r c h S t r I d=1057655898 \& \_$rerunOri gin $=$ google\&_acct $=C 000050480 \&$ version $=1 \&$ _url Version $=0 \& \_$userid $=1021790 \& \mathrm{md} 5=40 \mathrm{f} 470 \mathrm{a} 0 \mathrm{ed} 101 \mathrm{e}$ dcelfe 58a272ce7189.

Shuler, F.D., W.W. Chu, S. Wang and M.I. Evans, 1998 . A composite regulatory element in the first intron of the estrogen-responsive very low density apolipoprotein II gene. DNA Cell Biol., 17: 689-697. DOI: 10.1089/ dna.1998.17.689. PMID: 9726251. http://www.liebertonline.com/doi/abs/10.1089/dna.1998.17.689.

Tejada, M.L., Z. Jia, D. May and R.G. Deeley, 1999. Determinants of the dna-binding specificity of the avian homeodomain protein. AKR. DNA Cell. Biol., 18: 791-804. DOI: 10.1089/104454999314935. PMID: 10 541438.http://www.liebertonline.com/doi/abs/10.1089 \%2F104454999314935.
Wawro, K., E. Wilkiewicz, K. Kleczek and W. Brzozowski, 2004. Slaughter value and meat quality of muscovy ducks. Pekin ducks and their crossbreeds and evaluation of the heterosis effect. Arch. Tierz, 47:287-299.http://www.archanimbreed.com/pdf/2004/ at04p287.pdf.

Wiskocil, R., P. Goldman and R.G. Deeley, 1981. Cloning and structural characterization of an estrogendependent apolipoprotein gene. J. Biol. Chem., 256: 9662-9667. PMID: 6270095. http://www.jbc.org/ content/256/18/9662.full.pdf .

Yen, C.F., Y.N. Jiang, T.F. Shen, I.M. Wong, C.C. Chen, K.C. Chen, W.C. Chang, Y.K. Tsao and S.T. Ding, 2005. Cloning and expression of the genes associated with lipid metabolism in tsaiya ducks. Poult. Sci., 84: 67-74. PMID: 5685944. http://ps.fass.org/cgi/reprint/ 84/1/67.

Zsigmond, E., M.K. Nakanishi, F.E. Ghiselli and L. Chan, 1995. Transgenic Mouse model for estrogenregulated lipoprotein metabolism: Studies on ApoVLDL-II expression in transgenic mice. J. Lipid Res., 36: 1453-1 462. PMID: 7595069. http://www. jlr. org/cgi/reprint/36/7/1453.pdf. 